\title{
Comparative Analysis of Altman, Springate, and Zmijewski Models in Predicting the Bankruptcy of Retail Companies in Indonesia and Singapore
}

\author{
M. Muzanni a ${ }^{\text {iD }}$, Indah Yuliana a iD
}

${ }^{a}$ Department of Management, Faculty of Economic, Maulana Malik Ibrahim State Islamic University of Malang

\section{APA Citation:}

Muzanni, M., \& Yuliana, I. (2021). Comparative analysis of Altman, Springate and Zmijewski models in predicting the bankruptcy of retail companies in Indonesia and Singapore. TIJAB (The International Journal of Applied Business), 5(1), 81-93.

Submission Date: 19/02/2021

Acceptance Date: $18 / 04 / 2021$

\begin{abstract}
This study aimed to determine whether there is a difference in the prediction results between the Altman, Springate, and Zmijewski models and the most accurate prediction model for predicting the bankruptcy of retail companies in Indonesia and Singapore. This is descriptive quantitative research. The sampling method used was purposive sampling in which data was taken from 15 Indonesian retail companies and 15 Singapore retail companies. This study implemented descriptive analysis, normality test, and One Way ANOVA test using an SPSS program. The results showed that: 1) There were significant differences between the Altman model, Springate model, and Zmijewski model in Indonesian retail companies. 2) There was a significant difference between the Altman model, Springate model, and Zmijewski model in the Singapore retail companies. 3) The most accurate model in predicting the bankruptcy of Indonesian retail companies was the Zmijewski model. 4) The most accurate model in predicting the bankruptcy of Singapore retail companies was the Altman model.
\end{abstract}

Keywords: Altman; bankruptcy predictions; Springate; Zmijewski

This is an open access article under the CCBY-NC-SA license.

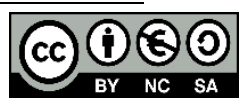

\section{Introduction}

The retail sector has a role and contribution in the development of the economy of a country. Based on the Asian Development Bank report (2019), the retail industry in Indonesia contributes $21 \%$ to the total Gross Domestic Product (GDP) of Indonesia. It is in the first place and the highest percentage in the retail sector compared to other ASEAN countries. Meanwhile, the retail industry in Singapore contributed 20\% to the Gross Domestic Product (GDP) of Singapore's retail sector, which is the secondlargest economic sector in ASEAN countries. However, this contrasts with the facts that have occurred

\footnotetext{
${ }^{1}$ Corresponding author.

E-mail address: m.muzanni19@gmail.com
} 
in the field where retail in Indonesia and Singapore have experienced a decline in sales growth in the last five years.

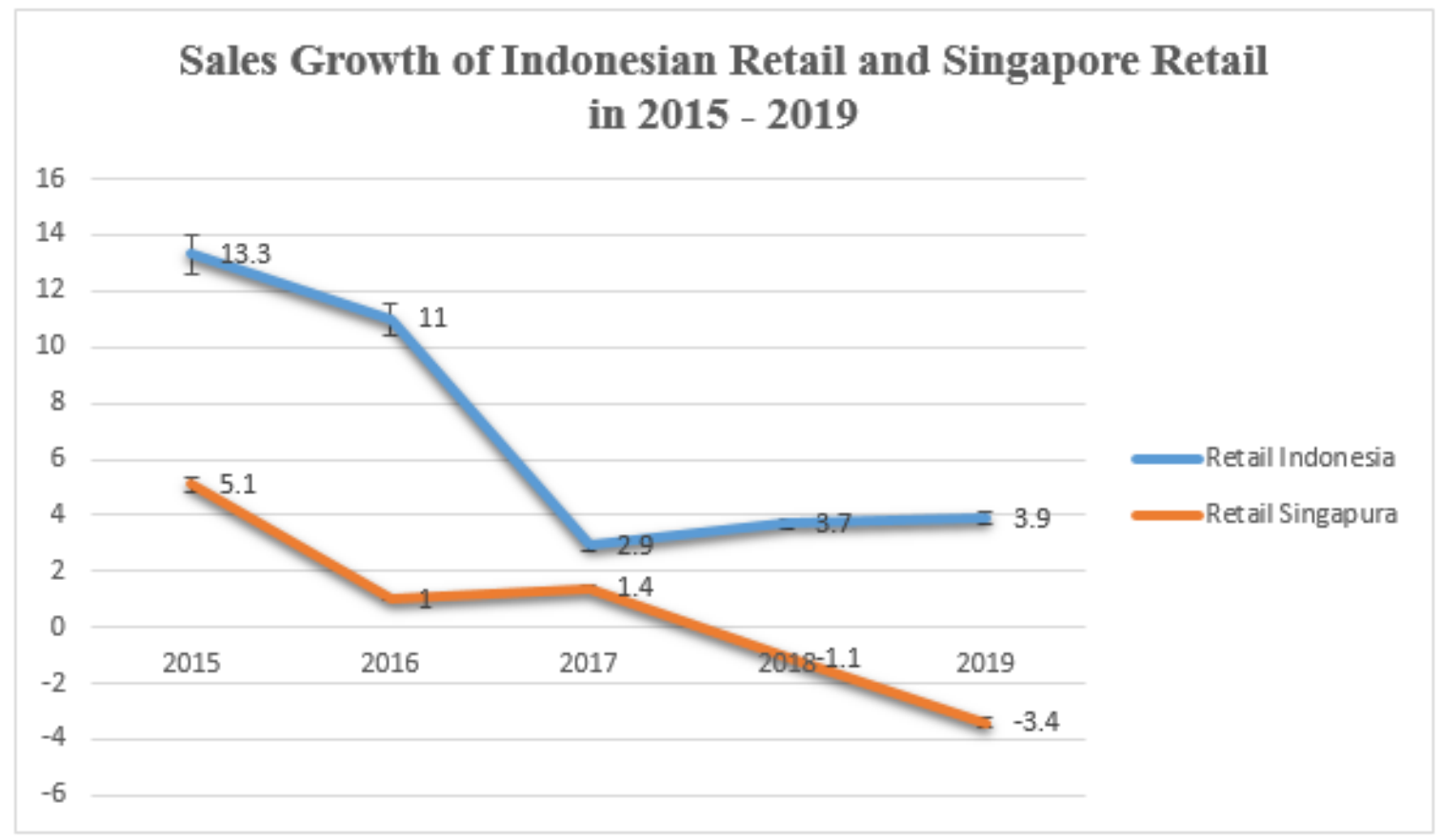

Source: Bank Indonesia (www.bi.go.id), Singapore Ministry of Trade and Industry (www.mit.gov.sg)

Figure 1. Sales Growth of Retail in Indonesian and Singapore

In 2017, the phenomenon of decreasing retail sales in Indonesia was indicated by the hypermarket and department store segments which experienced a decline in sales due to the emergence of ecommerce. This was a challenge that retail companies must face (www.bi.go. id). From 2017 to 2019, the average growth of Indonesian retail sales dropped to the double-digit average of the retail industry, which is in the range of 10 percent to 11 percent (Nielsen.com). Meanwhile, in Singapore retails, the decline in sales had been at minus in the last two years. This indicated that retails in Singapore wereworsen from year to year. Based on this fact, a bankruptcy prediction model is needed to see whether the financial condition of a retail company is healthy or not and to anticipate bankruptcy.

Previous research researched bankruptcy prediction models by finding different results or research gaps. Research conducted by Huda et al. (2019) showed significant differences in prediction results between the Altman, Springate, and Zmijewski models. This result contrasted with the results of research conducted by Ratri (2020) who found that the prediction model used did not show a significant difference. Besides, previous research also found differences in the level of accuracy of the results of each model. The research conducted by Raharja et al. (2017) which showed that the Altman model was the most accurate in predicting bankruptcy was one of them. Meanwhile, Mellisa and Banjarnahor (2020) found that the Springate model was the most accurate in predicting bankruptcy. However, Nilasari and Haryanto (2018) found that the Zmijewksi model was most accurate in predicting bankruptcy conditions.

Based on the phenomena described above and the differences in results, this study aimed to determine whether there were differences in the prediction results between the Altman, Springate, and Zmijewksi models applied to Indonesian retail companies and Singapore retail companies. Besides, the purpose of this study was also to determine the most accurate prediction model between Altman, Springate, and Zmijewski in Indonesian and Singapore retail companies from 2015 to 2019. The novelty in this study 
was that this study compared two objects of different countries. This study differed from previous researchers which data was only limited to one country. However, this research looked out to two countries, namely Indonesia and Singapore.

\section{Literature Review}

In essence, company bankruptcy is seen from the condition that the liabilities are greater than the assets owned by the company. Bankruptcy has a close relationship with the uncertainty of something unexpected about a company able to continue its operational activities due to the decline in the companies' financial condition (Lesmana and Surjanto, 2004:174).

\subsection{Altman Model}

Altman's model (1968) uses an approach based on a statistical technique called Multiple Discriminate Analysis (MDA) or the multivariate model. Altman's model (1968) could only predict bankruptcy in companies which belong to industry or manufacturing sector that go public. Then in 1983, he revised the Altman model to predict the bankruptcy of non-public manufacturing companies. In 1995, the Altman model was modified so it is not only limited to analyse public and non-public manufacturing companies, can but also be used to study various industries or sectors, both public and non-public. In this study, the Altman model that was used was Altman (1995) due to its relevancy to the object of this research. The formula of the modified Altman model is as follows:

$$
\mathrm{Z} \text {-Score }=6.56 \mathrm{X} 1+3.26 \mathrm{X} 2+6.72 \mathrm{X} 3+1.05 \mathrm{X} 4
$$

Remarks :

X1 = Working Capital / Total Assets (WCTA)

$\mathrm{X} 2$ = Reained Earnings / Total Assets (RETA)

$\mathrm{X} 3$ = Earning Before Interest and Taxes / Total Assets (EBITTA)

X4 = Book Value of Equity / Book Value of Debt (BVEBVD)

If the $\mathrm{Z}$ value $>2.60$, the company is categorized as not experiencing bankruptcy. If the value of 1.10 $\leq \mathrm{Z} \leq 2.60$, the company is classified as being in a grey area. If the value of $\mathrm{Z}<1.10$, the company is included in the category of bankruptcy.

\subsection{Springate Model}

Springate model (1978) was introduced by Gorgon L.V. Springate. The Springate model was a ratio model using the Multiple Discriminant Analysis (MDA) method which was employed to find 4 out of 19 financial ratios which are the best predictors of financial distress. The Springate model differs from other models as it distinguishes the healthy company with the bankrupt company. The Springate model modifies Altman's Multiple Discriminate Analysis (MDA) formula. However, the samples analyzed is different. The samples analysed using Springate model were companies in Canada while the Altman model analysed companies in America. The Springate model formula is:

$$
S=1.03 \mathrm{X} 1+3.07 \mathrm{X} 2+0,66 \mathrm{X} 3+0.4 \mathrm{X} 4 \text {. }
$$

Remarks :

X1 = Working Capital / Total Assets (WCTA)

$\mathrm{X} 2=$ Earning Before Interest and Taxes / Total Assets (EBITTA)

X3 = Earning Before Taxes / Current Liablities (EBTCL) 


\section{X4 = Sales / Total Assets (SATA)}

The cut-off value of this model is 0.862 . If the $Z$ value $<0.862$, it indicates that the company is bankrupt. If the $\mathrm{Z}$ value $>0.862$, the company is not considered bankrupt.

\subsection{Zmijewski Model}

Zmijewski's (1984) model uses the multivariate logit method as a statistical method, and random sampling as the sample selection method. Zmijewski reviewed previous research related to bankruptcy for over 20 years. The Zmijewksi model used financial ratios that also referred to previous studies between 1972 and 1978 that consisted of 75 samples of bankrupt companies and 73 samples of companies that were not bankrupt. The formula for the Zmijewski model is as follows:

$$
X=-4.3-4.5 X 1+5.7 X_{2}+0.004 X 3
$$

Remarks :

$\mathrm{X} 1=$ Net Income $/$ Total Assets $(\mathrm{ROA})$

$\mathrm{X} 2=$ Total Debt $/$ Total Assets (Leverage)

X3 = Current Assets / Current Liabilities (Liquidity)

The cut-off value of the Zmijewksi model is 0 . It means that companies that have an $\mathrm{X}$ value greater than or equal to 0 ise predicted to go bankrupt. Conversely, if a company has a value of $\mathrm{X}$ less than 0 , it will not go bankrupt. Based on the literature review, the conceptual framework model of this study is as follows:

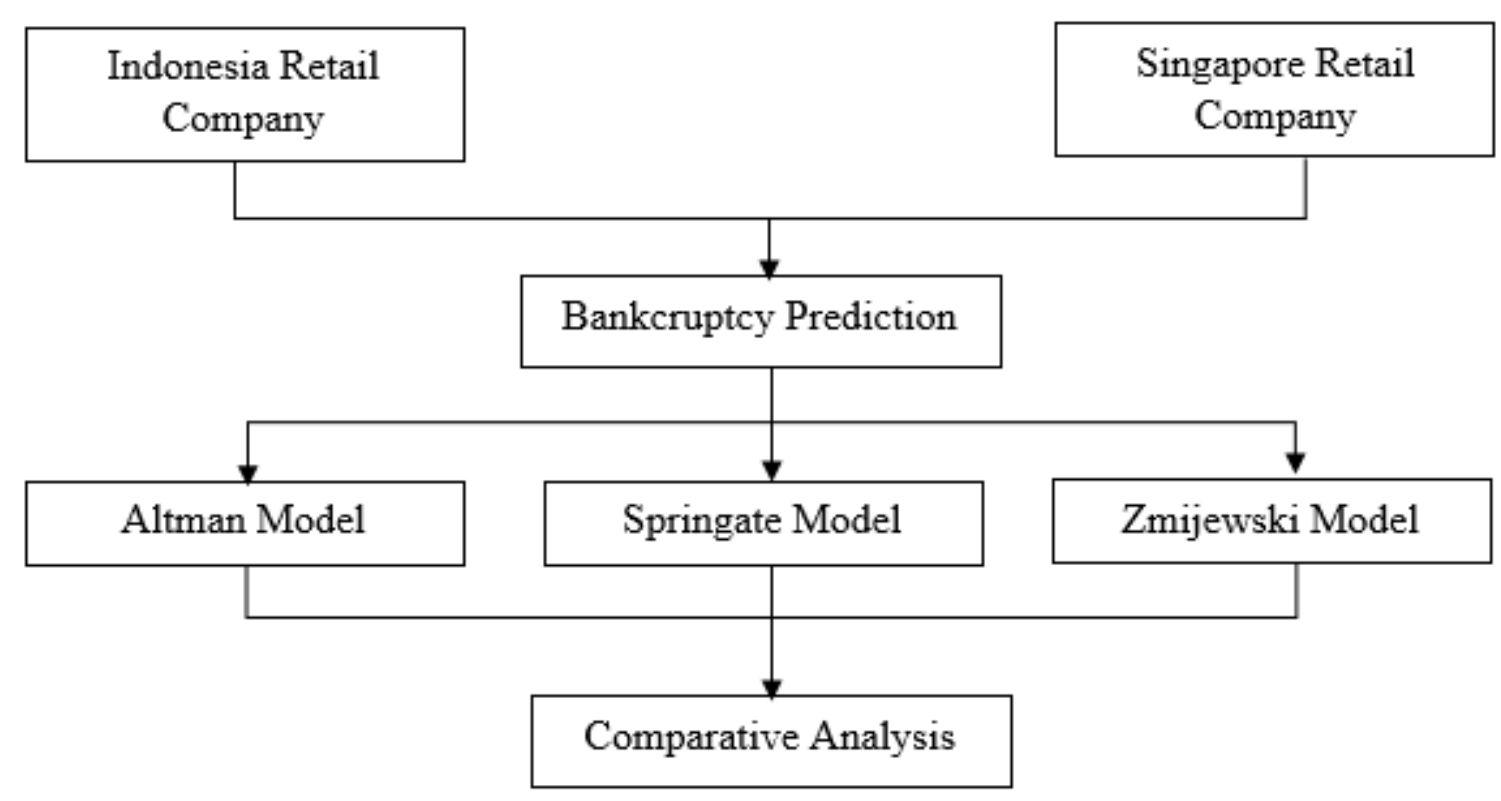

Figure 2. Conceptual Framework

\subsection{Research Hypothesis Development}

Lesmana and Surjanto (2004:174) stated that bankruptcy has a close relationship with the uncertainty of something unexpected occurring related to its ability to continue its operational activities due to the 
decline in the company's financial condition. Therefore, companies must make a bankruptcy prediction to determine the company's state. Several analysis models predict bankruptcy, including the Altman, Springate, and Zmijewski models and each model has different techniques, methods, variables, formulas, and determination of cut-off values in making the prediction. Huda et al. (2019) said that there were differences in the results of predictions between the Altman, Springate, and Zmijewski models in predicting bankruptcy in retail companies listed in the Indonesia Stock Exchange. Hence, the research hypothesis is listed as follows:

H1: There are differences in the result of bankruptcy predictions between the Altman, Springate, and Zmijewksi models in Indonesian retail companies.

$\mathrm{H} 2$ : There are differences in the results of bankruptcy predictions between the Altman, Springate, and Zmijewksi models in Singapore retail companies.

Zmijewski's model can be used as a bankruptcy prediction model with an accuracy of $94.9 \%$. This is supported by Nilasari and Haryanto's (2018) research, which stated that the Zmijewski Model is the most accurate model for predicting bankruptcy in retail companies listed on the Indonesia Stock Exchange with an accuracy rate of $97.9 \%$.

H3: Zmijewski's model is the most accurate in predicting the bankruptcy of Indonesian retail companies.

H4: Zmijewski's model is the most accurate in predicting the bankruptcy of Singapore retail companies.

\section{Method}

\subsection{Sample / Participants}

The number of sample in this study was different with the population of public retail companies in Indonesia and Singapore. The population of Indonesian retail companies is 27 companies, while in Singapore the retail companies are 43 companies. However, this study did not analyse all those companies as several sample criteria must be met. After applying the purposive sampling technique, the samples were listed as follows:

Tabel 1. Sample selection criteria

\begin{tabular}{lcc}
\hline \multicolumn{1}{c}{ Criteria } & \multicolumn{2}{c}{ Number of Companies } \\
\cline { 2 - 3 } & Indonesian Retail & Singapore Retail \\
\hline $\begin{array}{l}\text { Population of Retail Companies Listed on the State } \\
\text { Exchange }\end{array}$ & 27 & 43 \\
\hline $\begin{array}{l}\text { Companies that do not publish annual reports between } \\
2015-2019\end{array}$ & $(12)$ & (13) \\
\hline Number of Sample & 15 & 30 \\
\hline
\end{tabular}

Source : Processed by Author (www.idx.co.id and www.sgx.com).

The number of samples of Indonesian and Singaporean retail companies were different so it will cause difficulties during the testing process. Therefore, to make the number of the sample equal, we took out 15 sample retail in Singapore which had the highest level of liquidity. Hence, the number of retail companies analysed were 15 for each country.

\subsection{Data collection and Analysis}

In this study, the data collection technique that was employed was documentation techniques. Sugiyono (2018: 240) stated that documentation is a record of an event that has passed in the form of pictures, photos, sketches, and others. Implemented this technique, the data which in the form of annual 
reports between 2015 and 2019 were obtained from the official websites of the Indonesia Stock Exchange and Singapore Stock Exchange. Meanwhile, to analyse the data, we did descriptive statistics, normality testing, and hypothesis testing using the Statistical Product and Service Solutions (SPSS) program. In addition, the researchers also analysed the level of accuracy of each model. Fadrul and Ridawati (2020) stated that the formula for calculating the level of accuracy and the type of error was as follows:

$$
\begin{array}{ll}
\text { Accuracy Level } & =\frac{\text { Number of Correct Pedictions }}{\text { Number of Sample }} \times 100 \% \\
\text { Type of Error } 1 & =\frac{\text { Number of Indonesian Wrong Predictions }}{\text { Number of Indonesian Sample }} \times 100 \% \\
\text { Type of Error 2 } & =\frac{\text { Number of Singapore Wrong Predictions }}{\text { Number of Singapore Sample }} \times 100 \%
\end{array}
$$

\section{Results}

\subsection{Descriptive Statistical Analysis}

Descriptive statistics were used to provide an overview of data from each variable, including the amount of data, minimum value, maximum value, average value, and standard deviation (Ghozali, 2018: 19).

Tabel 2. Descriptive statistics of Indonesia

\begin{tabular}{cccccc}
\hline Variable & $\mathrm{N}$ & Minimum & Maximum & Mean & Std.Deviation \\
\hline WCTA & 75 & -0.26 & 0.86 & 0.22 & 0.26 \\
RETA & 75 & -0.34 & 1.11 & 0.26 & 0.32 \\
EBITTA & 75 & -0.29 & 0.60 & 0.07 & 0.14 \\
BVEBVD & 75 & 0.00 & 12.47 & 1.98 & 2.69 \\
EBTCL & 75 & -0.68 & 2.22 & 0.25 & 0.57 \\
SATA & 75 & 0.08 & 6.54 & 1.96 & 1.13 \\
ROA & 75 & -0.23 & 0.46 & 0.04 & 0.11 \\
Leverage & 75 & 0.07 & 0.88 & 0.50 & 0.24 \\
Liquidity & 75 & 0.64 & 14.03 & 2.62 & 2.82 \\
\hline
\end{tabular}

Table 2. showed the results of descriptive statistics, which include the minimum value, maximum value, the mean and standard deviation of the variables WCTA, RETA, EBITTA, BVEBVD, EBITCL, SATA, ROA, Leverage and Liquidity. The amount of data is 75 sample data of retail companies that were listed in the Indonesia Stock Exchange (IDX).

Tabel 3. Descriptive Statistics Singapore

\begin{tabular}{cccccc}
\hline Variable & $\mathrm{N}$ & Minimum & Maximum & Mean & Std.Deviation \\
\hline WCTA & 75 & -0.25 & 0.64 & 0.33 & 0.23 \\
RETA & 75 & -1.46 & 0.76 & 0.26 & 0.38 \\
EBITTA & 75 & -0.62 & 0.20 & 0.03 & 0.11 \\
BVEBVD & 75 & 0.06 & 10.76 & 2.74 & 2.50 \\
EBTCL & 75 & -0.88 & 1.24 & 0.22 & 0.36 \\
\hline
\end{tabular}




\begin{tabular}{cccccc}
\hline SATA & 75 & 0.10 & 3.16 & 1.07 & 0.65 \\
ROA & 75 & -0.62 & 0.16 & 0.02 & 0.10 \\
Leverage & 75 & 0.08 & 3.12 & 0.44 & 0.40 \\
Liquidity & 75 & 0.65 & 6.66 & 2.59 & 1.46 \\
\hline
\end{tabular}

Table 3. illustrated the results of descriptive statistics include the minimum value, maximum value, a mean and standard deviation of the variables WCTA, RETA, EBITTA, BVEBVD, EBITCL, SATA, ROA, Leverage, and Liquidity, and the amount of data is 75 samples of retail company data that were listed in the Singapore Exchange (SGX).

\subsection{Bankruptcy Analysis Results in Indonesian Retail}

\subsubsection{Altman Model}

Based on calculation results of the Altman model, several companies are predicted to go bankrupt, namely PT Midi Utama Indonesia Tbk 2015 - 2019, PT Kokoh Inti Arebama Tbk 2019, and PT Matahari Putra Prima Tbk. These companies were predicted to go bankrupt due to the negative WC/TA values. This value indicated that the current debt of each company was greater than current assets. In addition, the RE / TA value is also negative, which means that the assets owned are not managed optimally, making it difficult both in terms of funding and investment.

\subsubsection{Springate Model}

Based on the calculation results of the Springate model, several companies are predicted to go bankrupt, namely PT Centratama Telekomunikasi Indonesia Tbk in 2015 - 2019, PT Hero Supermarket Tbk in 2015, 2017, and 2018 and PT Matahari Putra Prima Tbk in 2017 - 2019. The EBIT / TA value of these companies were negative. This indicated that these companies were not able to manage their assets to generate net income before taxes and interest. In addition, the value of EBT / CL of these companies was negative. In other words, these companies were unable to manage its current debt to generate net profit before tax.

\subsubsection{Zmijewski Model}

Based on the calculation of the Zmijewski model, the company which were predicted to go bankrupt for five consecutive years was PT Kokoh Inti Arebama Tbk as its ROA value was negative. Leverage that has a high value means that the total debt is greater than the total assets owned by the company.

\subsection{Bankruptcy Analysis Results in Singapore Retail}

\subsubsection{Altman Model}

The calculation of the Altman model indicated that several companies there were several retail companies that were predicted to go bankrupt, namely Parkson Retail Asia Ltd, during 2015 - 2019 and Sitra Holding International Ltd in 2019. The calculation showed that the value of WC / TA of these company were negative. This means that current debt was greater than current assets. Also, the RE / TA value is also negative. This indicated that the assets were not 
managed optimally. The BVE / BVD value of these companies was found to be low. This means that the companies' ability to guarantee their debts through capital was still low.

\subsubsection{Springate Model}

Based on the calculation of the Springate model, several companies are predicted to go bankrupt, including Jardine Cycle \& Carriage Ltd, Ossia International Ltd, Parkson Retail Asia Ltd, Second Chance Properties Ltd, and Sitra Holding International Ltd, Aspial Corporation Ltd, and Stamford Ryres Corporation Ltd, for five consecutive years 2015 - 2019 and Tye Soon Limited in 2015 and 2019. This prediction was drawn after the BIT / TA value appeared to be negative. This implied that that these companies were unable to manage its assets in generating net profit before interest and taxes. In addition, the EBT / CL values of these companies were also negative which meanss that these companies were unable to manage their current debt to generate net profit before tax. Their SA / TA values were also low which means that the company's ability to use its total assets to generate sales were still lows.

\subsubsection{Zmijewski Model}

Based on the results of Zmijewski's capital calculations, Parkson Retail Asia Ltd and Stamford Ryres Corporation Ltd were predicted to go bankrupt as their ROA values were negative. This indicated that the companies were unable to manage their assets to generate a net profit. In addition, their leverage value were high which means that the total debt was greater than the total assets. Also, their slow liquidity values indicated that those companies' ability to meet their current obligation were still low.

\subsection{Recap of the Calculation Results of Altman, Springate and Zmijewski Models}

Tabel 4. Recap of the Calculation Results of Altman, Springate and Zmijewski Models

\begin{tabular}{ccccc}
\hline Model & \multicolumn{3}{c}{ Prediction Results } & Total Sample \\
\cline { 2 - 4 } data
\end{tabular}

\subsection{Normality Test Results}

The normality test is used to determine whether the data is considered normal distribution or not. To test this, this study used the Kolmogorov Smirnov K-S method. The data was the considered to be normal if the value was Asymp. Sig. (2-taled) $>0.05$. Otherwise, the data was considered not normal if the value was Asymp. Sig. (2-taled) <0.05 (Ghozali, 2018: 161).

Table 4. One-Sample Kolmogrov-Smirnov Test

\begin{tabular}{llcccccc}
\hline & & $\begin{array}{c}\text { Altman } \\
\text { Indonesia }\end{array}$ & $\begin{array}{c}\text { Springate_ } \\
\text { Indonesia }\end{array}$ & $\begin{array}{c}\text { Zmijewski_ } \\
\text { Indonesia }\end{array}$ & $\begin{array}{c}\text { Altman_ } \\
\text { Singapore }\end{array}$ & $\begin{array}{c}\text { Sepringate_ } \\
\text { Singapore }\end{array}$ & $\begin{array}{c}\text { Zmijewski_ } \\
\text { Singapore }\end{array}$ \\
\hline $\mathrm{N}$ & & 75 & 75 & 75 & 75 & 75 & 75 \\
Normal & Mean & 4.858 & 1.386 & -1.612 & 6.129 & 1.023 & -1.869 \\
Parameters & Std. D & 4.771 & 0.910 & 1.543 & 4.328 & 0.758 & 2.497 \\
Most & Absolut & 0.164 & 0.147 & 0.122 & 0.074 & 0.072 & 0.209 \\
Extreme & Positive & 0.164 & 0.147 & 0.088 & 0.074 & 0.072 & 0.209 \\
Differences & Negatif & -0.104 & -0.102 & -0.122 & -0.070 & -0.042 & -0.186 \\
& & & & & & &
\end{tabular}




\begin{tabular}{lllllll}
\cline { 2 - 7 } Kolmogrov-Smirnov Z & 1.319 & 1.277 & 1.057 & 0.638 & 0.626 & 1.148 \\
Asymp. Sig. (2-tailed) & 0.063 & 0.077 & 0.214 & 0.811 & 0.827 & 0.103
\end{tabular}

a. Test distribution is Normal.

Table 4 showed that based on the data normality test results on Indonesian retailers and Singapore retailers, the Asymp test value were Sig (2-tailed) Altman model in Indonesia was 0.063>0.05, Springate model in Indonesia was 0.077> 0.05, and Zmijewski model Indonesia 0.214>0.05. Meanwhile, the Asymp test value of Altman model in Singapore was 0.811>0.05, Springate Model in Singapore was $0.827>0.05$, and Zmijewski Model was 0.103>0.05. hence, it implied that the data was normally distributed or the normality test was fulfilled.

\subsection{Hypothesis test results}

In conducting hypothesis testing, the researcher used the One Way Anova test to find whether there were differences in the prediction results between the Altman, Springate, and Zmijewski models. During the test, if the significance value was $>0.05$, then there was no difference. However, if the significance value was $<0.05$, then there was a difference. The results of the One Way Anova test are as follows:

Table 5. ANOVA Indonesia

\begin{tabular}{cccccc}
\hline Prediction Results & Sum of Squares & df & Mean Square & F & Sig. \\
\hline Between Groups & 1572.687 & 2 & 786.344 & 90.831 & .000 \\
Within Groups & 1921.911 & 222 & 8.657 & & \\
Total & 3494.598 & 224 & & &
\end{tabular}

Source: Processed by author (2021)

Table 5 revealed that the significance value of the ANOVA test was $0.000<0.05$, which means that there were differences in the prediction results between Altman, Springate, and Zmijewski models in predicting the Indonesian retail companies. In other words, H1 was accepted.

Table 6. ANOVA Singapore

\begin{tabular}{cccccc}
\hline Prediction Results & Sum of Squares & df & Mean Square & F & Sig. \\
\hline Between Groups & 2460.067 & 2 & 1230.033 & 144.485 & .000 \\
Within Groups & 1889.936 & 222 & 8.513 & & \\
Total & 4350.002 & 224 & & &
\end{tabular}

Source: Processed by author (2021)

Table 6 indicated that the ANOVA test results showed a significance value of $0.000<0.05$. This means that there were differences in the prediction results between the Altman, Springate, and Zmijewski models in Singapore retail companies. So, H2 was accepted.

Table 7. Comparison of the level of accuracy of the prediction model on Indonesian Retail

\begin{tabular}{ccc}
\hline Model & Level of Accuracy & Type Error \\
\hline Altman & $60 \%$ & $40 \%$ \\
Springate & $80 \%$ & $30 \%$ \\
Zmijewski & $87 \%$ & $13 \%$ \\
\hline
\end{tabular}


Table 7 indicated that the Zmijewski model was the most accurate prediction model in predicting the bankruptcy of Indonesian retail companies with an accuracy rate of $87 \%$ and error rate of $13 \%$. So, H3 was accepted.

Table 8. Comparison of the level of accuracy of the prediction model on Singapore Retail

\begin{tabular}{ccc}
\hline Model & Level of Accuracy & Type Error \\
\hline Altman & $86 \%$ & $14 \%$ \\
Springate & $60 \%$ & $40 \%$ \\
Zmijewski & $73 \%$ & $27 \%$ \\
\hline
\end{tabular}

Based on Table 8, the Altman Model was the most accurate prediction model in predicting the bankruptcy of Singapore retail companies with an accuracy rate of $86 \%$ and error rate of $14 \%$. So, H4 was rejected.

\section{Discussion}

H1: There was a difference in prediction results between the Altman, Springate and Zmijewski Models in Indonesian Retail Companies

Based on the results of hypothesis testing using the One Way Anova test, the prediction results had a significance value of $0.000>0.05$, which means that there were differences in the prediction results between the Altman, Springate, and Zmijewski models that were applied to predict the Indonesian retail companies' bankruptcy. The difference in the results of the predictions of each model was due to the different variables of each model. As Nur Cahyati (2015) stated, the difference in prediction results occured due to differences in the variables used by each model and the coefficients in the calculation of the formula for each prediction model so that the results of bankruptcy predictions were different.

The results of this study were in line with research conducted by Melissa and Banjarnahor (2020), which states that the Altman, Springate, and Zmijewski models have different predictions because the formulas of each model are different. Huda et al. (2019) found different score in the prediction models of Altman, Springate, and Zmijewski. Nenengsih (2018) mentioned that the difference in predictions from each model lied in the ratio used as Springate model emphasized the profitability ratio to be the determinant of the final score, while Zmijewski emphasized the leverage ratio, namely total debt, and total assets.

$\mathrm{H} 2$ : There was a difference in prediction results between the Altman, Springate and Zmijewski Models in Singapore Retail Companies

Based on the results of hypothesis testing using the One Way Anova test, the prediction results showed a significance value of $0.000>0.05$, which means that there were differences in the prediction results between the Altman, Springate, and Zmijewski models that were applied to the prediction of Singapore retail companies' bankruptcy. The difference in the results of the predictions of each model occurred due to the different variables of each model.

Tanjung (2020) stated that there were differences in each prediction model because the measurements of each model were different. Winaya et al. (2020) who showed the results that each model has different predictions mentioned that it happened because the ratios used as variables in the analysis were different between each prediction model. Permana et al. (2017) said that the prediction results of each model were different because each prediction model had different components or variables. 
H3: Zmijewski's model was the most accurate in predicting the bankruptcy of Indonesian retail companies.

From the results of the prediction analysis of the three models, the Zmijewski model was the most accurate prediction model in predicting the bankruptcy of Indonesian retail companies with an accuracy rate of $87 \%$ and error rate of $13 \%$. The primary reason to this was that the Zmijewski Model can predict the largest sample of company data that is not bankrupt among the other models. The results of this study were in line with research conducted by Nilasari and Haryanto, (2018) Munawaroh et al, (2019); and Huda et al, (2019).

H4: Zmijewski's model was the most accurate in predicting the bankruptcy of Singapote retail companies.

From the prediction results of the three models, the Altman model was the most accurate prediction model in predicting the bankruptcy of Singapore retail companies with an accuracy rate of $86 \%$ and error rate of $14 \%$. This is because the Altman Model can predict the largest sample of company data that is not bankrupt among the other models. The results of this study were in line with Raharja et al, (2017), Harsono and Yoewono (2018) and Tanjung (2020).

\section{Conclusions}

The previous sections led to a conclusion that there were significant differences between the Altman, Springate, and Zmijewski models in predicting the bankruptcy of Indonesian retail companies. Analysis using Altman model showed that 11 sample data companies were expected to go bankrupt, while the other 23 were prone to default. Analysis using the Springate model revealed that 14 sample companies were predicted to be bankrupt. In addition, Zmijewski model predicted that 10 sample data companies to go bankrupt.

Analysis on Singapore Retail showed that there a significant difference between the Altman, Springate, and Zmijewski models in predicting the bankruptcy of Singapore retail companies. Altman's model predicts 6 data samples to be bankrupt and 5 sample data prone to default. Analysis using the Springate model, showed that 35 sample data companies were expected to go bankrupt. Meanwhile, the Zmijewski model predicted that 14 company samples to go bankrupt.

The most accurate model in predicting the bankruptcy of Indonesian retail companies was the Zmijewski model. Meanwhile, the most accurate model in predicting the bankruptcy of Singapore retail companies was the Altman model.

This study had several limitations. Firsly, this study only analyse the retail sectors in two countries: Singapore and Indonesia. Second, among the retail companies, there were only 15 companies that met the sample criteria. Hence, the data was limited to 15 companies in each country. Lastly, this study only observed the annual report of each company within five years period. Therefore, it is suggested that other researchers should develop this study by increasing the number of sectors, samples, and observation period as well as the countries that were being analysed.

\section{References}

Altman, E.L. (1968). Financial Ratios, Discriminat Analysisi and the Prediction of Corporate Bankruptcy. The Journal of Finance, 23 (4), pp.589-609.

Fadrul and Ridawati. (2020). Analysis of Method Used to Predict Financial Distress Potencial in Pulp and Paper Companies of Indonesia. International Journal of Economics Development Research, 1(1), pp.57-69. 
Harsono., \& Yoewono. (2018). Bankruptcy Prediction Models Applied on Companies Listed on the Indonesian Stock Exchange (IDX). Journal of Management and Leadership, 1(2), pp.1-18.

Huda, E.N., Paramita, D.P., and Amboningtyas, D. (2019). Analisis Financial Distress Menggunakan Model Altman, Springate dan Zmijewski pada Perusahaan Retail yang terdaftar di BEI 2013-2017. Journal of Management, 5(5), pp.1-11.

Lesmana, R., \& Surjanto, R. (2004). Financial Performance Analysis. Jakarta: Elex Media Komputindo.

Permana, R.K., Ahmar, N., \& Djaddang, S.(2017). Prediksi Financial Distress pada Perusahaan Manufaktur di Bursa Efek Indonesia. Esensi: Jurnal Bisnis dan Manajemen, 7(2), pp.149-166.

Raharja, D,B,B., Wahyuni, M,A., \& Sinarwati, N, K. (2017). Analisis Prediksi Kebangkrutan dengan Metode Analisis Z-Score Model Altman, Model Springate, dan Model Zmijewski pada Perusahaan Property dan Real Estate Go Public di Bursa Efek Indonesia tahun 2013-2015. E-Journal Universitas Pendidikan Ganesha, 8(2), pp.1-12.

Ratri, A.M. (2020). Model Prediktor Potensi Kesulitan Keuangan Perusahaan Retail di Indonesia. Jurnal Bisnis dan Manajemen, 7(1), pp.46-54.

Mellisa, P., and Banjarnahor, H. (2020). Analisis Prediksi Kebangkrutan Menggunakan Model Altman Z-Score, Springate dan Zmijewski yang terdaftar di Bursa Efek Indonesia. Jurnal EMBA, 8 (1), pp.903-912.

Munawarah., Wijaya, A., Fransisca, C., \& Felicia. (2019). Ketepatan Altman, Zmijewski, Grover, dan Fulmer menentukan Financial Distress pada Perusahaan Trade and Service. Owner Riset \& Jurnal Akuntansi, 3(2), pp.278-288.

Nenengsih. (2018) Model Prediksi Springate Sebagai Prediktor Delisting Terbaik dibandingkan Model Zmiejwski. Menara Ekonomi, 4(2), pp.69-77.

Nilasari, D., \& Haryanto, M. (2018). Memprediksi Perusahaan yang Berpotensi Mengalami Masalah Keuangan dengan Model Altman, Springate dan Zmijewksi. Jurnal STIE Semarang, 10(1), pp.116.

Nurcahyanti, W. (2015). Studi Komparatif Model Z-Score Altman, Springate dan Zmijewski dalam Mengindikasikan Kebangkrutan Perusahaan yang Terdaftar di BEI. Artikel Ilmiah, pp.1-22.

Sugiyono. (2018) Metode Penelitian Kuantitatif. Bandung: Alfabeta.

Springate, G.L.V. (1978). Predicting the Possibility of Failure in a Canadian Firm. M.B.A Research Project, Simon Fraser University. January.

Tanjung, P.R.S. (2020). Comparative Analysis of Altman Z-Score, Springate, Zmijewksi and Ohlson Models In Predicting Financial Ditress. EPRA International Journal of Multidiscriplinary Research (IJMR), 6(3), pp.126-137.

Winaya, G.Y., and RM, Ketut, M.(2020). Analysis of Altman Z-Score and Zmijewksi Bankruptcy Prediction in Telecomunication Sub-Sector Registered in Indonesia Stock Exchange in 2016-2018. American Journal of Humanities and Social Sciences Research (AJHSSR), 4(1), pp.313-322.

Zmijewski, M. (1984). Methodological Issues Related to the Estimation of Financial Distress Prediction Models. Journal Account, 22, pp.59-82. 


\title{
Analisis Perbandingan Model Altman, Springate dan Zmijewski dalam Memprediksi \\ Kebangkrutan Perusahaan Ritel di Indonesia dan Singapura
}

\begin{abstract}
Abstrak
Penelitian ini bertujuan untuk mengetahui ada tidaknya perbedaan hasil prediksi antara model Altman, Springate dan Zmijewski dan model prediksi yang paling akurat untuk memprediksi kebangkrutan perusahaan ritel Indonesia dan Singapura. Jenis penelitian ini adalah deskriptif kuantitatif. Metode pengambilan sampel menggunakan Purposive sampling dengan 15 perusahaan ritel Indonesia dan 15 perusahaan ritel Singapura. Analisis data dalam penelitian ini menggunakan analisis deskriptif, uji normalitas, dan uji One Way ANOVA dengan menggunakan program SPSS. Hasil penelitian menunjukkan bahwa : 1) Terdapat perbedaan yang signifikan antara model Altman, model Springate dan model Zmijewski pada perusahaan ritel Indonesia. 2) Terdapat perbedaan yang signifikan antara model Altman, model Springate dan model Zmijewski pada perusahaan ritel Singapura. 3) Model yang paling akurat dalam memprediksi kebangkrutan perusahaan ritel Indonesia adalah model Zmijewski. 4) Model yang paling akurat dalam memprediksi kebangkrutan perusahaan ritel Singapura adalah model Altman.
\end{abstract}

Kata kunci: altman; springate; zmijewski; prediksi kebangkrutan 